Preprint

UCRL-JC-140535

\title{
Current Directions in Screening-Level Ecological Risk Assessments
}

T. M. Carlsen, R. A. Efroymson

This article was submitted to Society of Plastics Engineers/Environmental ProtectionAgency/ Department of Energy Exploration and Production Environmental Conference

San Antonio, TX

February 26-28, 2001

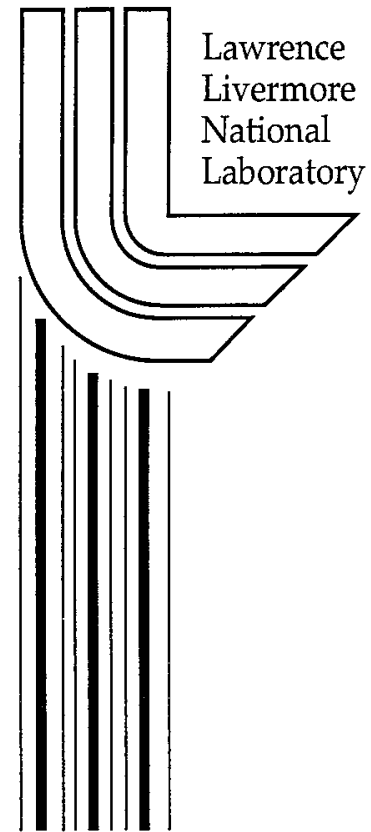

December 11, 2000 


\section{DISCLAIMER}

This document was prepared as an account of work sponsored by an agency of the United States Government. Neither the United States Government nor the University of California nor any of their employees, makes any warranty, express or implied, or assumes any legal liability or responsibility for the accuracy, completeness, or usefulness of any information, apparatus, product, or process disclosed, or represents that its use would not infringe privately owned rights. Reference herein to any specific commercial product, process, or service by trade name, trademark, manufacturer, or otherwise, does not necessarily constitute or imply its endorsement, recommendation, or favoring by the United States Government or the University of California. The views and opinions of authors expressed herein do not necessarily state or reflect those of the United States Government or the University of California, and shall not be used for advertising or product endorsement purposes.

This is a preprint of a paper intended for publication in a journal or proceedings. Since changes may be made before publication, this preprint is made available with the understanding that it will not be cited or reproduced without the permission of the author.

This work was performed under the auspices of the United States Department of Energy by the University of California, Lawrence Livermore National Laboratory under contract No. W-7405-Eng-48.

This report has been reproduced directly from the best available copy.

Available electronically at http://www.doc.gov/bridge

Available for a processing fee to U.S. Department of Energy

And its contractors in paper from

U.S. Department of Energy

Office of Scientific and Technical Information

P.O. Box 62

Oak Ridge, TN 37831-0062

Telephone: (865) 576-8401

Facsimile: (865) 576-5728

E-mail: reports@adonis.osti.gov

Available for the sale to the public from

U.S. Department of Commerce

National Technical Information Service

5285 Port Royal Road

Springfield, VA 22161

Telephone: (800) 553-6847

Facsimile: (703) 605-6900

E-mail: orders@ntis.fedworld.gov

Online ordering: http://www.ntis.gov/ordering.htm

OR

Lawrence Livermore National Laboratory

Technical Information Department's Digital Library

http://www.llnl.gov/tid/Library.html 


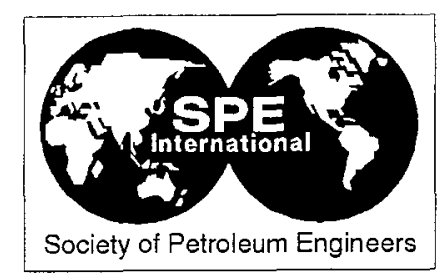

\title{
SPE 68319
}

\author{
Current directions in screening-level ecological risk assessments \\ T. M. Carlsen, Lawrence Livermore National Laboratory, Livermore, California and R. A. Efroymson, Oak Ridge National \\ Laboratory, Oak Ridge, Tennessee
}

\begin{abstract}
Copyright 2001, Society of Petroleum Engineers Inc.
This paper was prepared for presentation at the SPE/EPAJDOE Exploration and Production Environmental Conference heid in San Antonio, Texas, 26-28 February 2001.

This paper was selected for presentation by an SPE Program Committee following review of information contained in an abstract submitted by the author(s). Contents of the paper, as information contained in an abstract submitted by the author(s). Contents of the paper, as correction by the author(s). The material, as presented, does not necessarily reflect any position of the Society of Petroleum Engineers, its officers, or members. Papers presented a SPE meetings are subject to publication review by Editorial Committees of the Society of Petroleum Engineers. Electronic reproduction, distribution, or storage of any part of this pape for commercial purposes without the written consent of the Society of Petroleum Engineers is prohibited. Permission to reproduce in print is restricted to an abstract of not more than 300

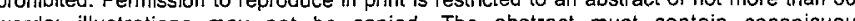
words; illustrations may not be copied. The abstract must contain conspicuous
acknowledgment of where and by whom the paper was presented. Write Librarian, SPE, P.O. acknowledgment of where and by whom the paper was presented. Write
\end{abstract}

\begin{abstract}
Ecological risk assessment (ERA) is a tool used by many regulatory agencies to evaluate the impact to ecological receptors from changes in environmental conditions. Widespread use of ERAs began with the United States Environmental Protection Agency's Superfund program to assess the ecological impact from hazardous chemicals released to the environment. Many state hazardous chemical regulatory agencies have adopted the use of ERAs, and several state regulatory agencies are evaluating the use of ERAs to assess ecological impacts from releases of petroleum and gasrelated products. Typical ERAs are toxicologically-based, use conservative assumptions with respect to ecological receptor exposure duration and frequency, often require complex modeling of transport and exposure and are very labor intensive. In an effort to streamline the ERA process, efforts are currently underway to develop default soil screening levels, to identify ecological screening criteria for excluding sites from formal risk assessment, and to create risk-based corrective action worksheets. This should help reduce the time spent on ERAs, at least for some sites. Work is also underway to incorporate bioavailability and spatial considerations into ERAs. By evaluating the spatial nature of contaminant releases with respect to the spatial context of the ecosystem under consideration, more realistic ERAs with respect to the actual impact to ecological receptors at the population, community or ecosystem scale should be possible. In addition, by considering the spatial context, it should be possible to develop mitigation and monitoring efforts to more appropriately address such sites within the context of an ecological framework.
\end{abstract}

\section{Introduction}

Risk assessment is a valuable tool for land managers faced with determining the potential for adverse environmental effects from human activities. In a risk assessment, the potential magnitude of an adverse effect, as well as the probability that such an effect is likely to occur is assigned to actions under consideration. Possible outcomes of an activity can then be ranked based on the risk assessment results. This provides managers with a basis to choose among alternatives (such as whether or not to actively remediate chemical contamination in the environment). Risk assessment has become a primary component of environmental decision making because of the recognition that (1) it is far too costly to eliminate all potentially adverse environmental effects from human activities, and (2) decisions must often be made in the face of incomplete scientific data ${ }^{1}$. Risk assessment allows site managers to balance the degree of risk with the cost of reducing that risk.

The need to protect ecological properties in addition to human health is generally accepted by most governmental entities involved in contaminated site cleanup and restoration. This has resulted in the use of ecological risk assessments (ERAs) to evaluate the potential impact contaminants may have on a site's ecological receptors. The use of ecological risk assessment has its roots in the United States Environmental Protection Agency's (EPA's) program to implement the Comprehensive Environmental Response, Compensation and Liability Act (Superfund), which focuses on cleaning up hazardous waste sites. Other EPA programs implementing major environmental legislation (Clean Air Act, Clean Water Act, Federal Insecticide/Fungicide and Rodenticide Act, Solid Waste Disposal Act) also require EPA to consider environmental impacts. As a consequence, the EPA has produced a wide array of guidance documents describing a variety of ERA methods s, $3,4,5,6^{\text {. }}$

Thus, the EPA has become the primary "standard bearer" for the use of ERAs. ERA methods developed by the EPA are often adopted by state and local regulatory agencies. As a consequence, managers and operators of upstream petroleum exploration and production (E\&P) facilities may find themselves faced with interacting with state regulatory agencies which are beginning to require more thorough assessment of ecological impacts of inadvertent releases. It is 
therefore important to be aware of the types of ecological risk assessments that are currently being done, directions in which risk assessment techniques are evolving, and their applicability to gas and petroleum exploration and production facilities.

\section{Ecological Risk Assessment Basics}

ERAs follow a stepwise process from an initial evaluation through a detailed investigation (Fig. 1). Through a site visit, the general ecological setting is determined. A preliminary analysis of the type and quantity of contamination is conducted, as well as an analysis of potential ecological exposure pathways (Fig. 2). Initial ecological assessment and measurement endpoints are selected, and a preliminary evaluation of available toxicological benchmarks is conducted. A screening level risk calculation is then conducted. At this point, a management decision is made concerning the need to conduct additional analysis, site remediation, or no further action.

Endpoint selection is key to the entire process. Endpoints are characteristics of an ecological component that may be affected by exposure to a stressor ${ }^{2}$. Assessment endpoints are explicit expressions of the actual environmental value to be protected. An assessment endpoint should:

- have societal relevance

- have biological or ecological relevance

- have an unambiguous operational definition

- be measurable or predictable

- be susceptible to the hazard

- be logically related to the decision under consideration ${ }^{7}$

In general, plants and animals are not valued biologically as individuals, and therefore assessment endpoint entities are typically populations, communities, or ecological function. The exception to this is federal or state-listed threatened or endangered species. In this case, each individual is presumed critical to the survival of the species. In addition to the endpoint entity, an ecological assessment endpoint consists of a property of that entity, such as abundance or production of a population, or diversity of a community.

The actual mechanics of conducting an ERA can vary greatly depending on the biological characteristics of the site, the type, quantity and aerial extent of contamination, the quality and quantity of data available, and the regulatory framework within which the site is operating. Many of the current developments on ERAs have been directed towards simplifying the process and improving their biological and ecological relevance.

\section{Screening-level ERAs}

In the early phases of an ERA, most assessors at most sites will use a form of the Hazard Quotient method (HQ) to conduct initial risk calculations, and possibly follow-up with bioassays appropriate for the ecological receptors found at the site. The $\mathrm{HQ}$ method involves modeling exposures to ecological receptors expected to occur at the site and comparing these results to toxicological benchmarks derived from the published literature. For example, exposure for vertebrate species could be modeled as total daily intake of contaminant:

$$
\mathrm{TDI}_{i}=\Sigma \mathrm{C}_{\mathrm{em}} \cdot \mathrm{I}_{\mathrm{r}}
$$

Where $\mathrm{TDI}_{i}=$ total daily intake of contaminant for pathway $i(\mathrm{mg} /$ day $), \mathrm{C}_{\mathrm{em}}=$ concentration of contaminant in exposure media $(\mathrm{mg} / \mathrm{kg}), \mathrm{I}_{\mathrm{r}}=$ daily intake rate of exposure media (mg/day). Total daily exposure for pathway $i$ is estimated by dividing the $\mathrm{TDl}_{i}$ by the animal body weight. The exposure pathways usually considered are incidental soil ingestion (through grooming, feeding, etc.) and ingestion of contaminated food items (the concentration of which are estimated using contaminant soil concentrations and bioconcentration factors derived from the literature). Depending on the contaminant and receptors involved, the inhalation pathway may also be considered ${ }^{9,10}$. Exposure model assumptions are usually conservative, i.e. wildlife species are assumed to reside $100 \%$ of the time in contaminated areas, and consume $100 \%$ contaminated food items. Bioavailability of the contaminant is sometimes assumed to be $100 \%$. The soil concentrations utilized in the model are usually the maximum observed concentration for the contaminant, or the upper $95 \%$ confidence level on the mean concentration. For plants and soil invertebrates, soil concentrations can be directly compared to toxicological benchmarks.

Benchmarks are derived from toxicological data found in the literature (Table 1). An attempt is made to locate toxicological studies using closely related species that measured effects of ecological relevance (such as reproduction), with results reported as either the lowest observable adverse effect concentration (LOAEC) or no observable adverse effect concentration (NOAEC) $)^{8,11}$. Toxicological benchmarks tend to be conservative estimates of toxicity, because the bioavailability of the salts added to soil in tests from which benchmarks are derived tends to be higher than that of the chemical in field soils.

The Hazard Quotient is calculated by dividing the estimated exposure by the benchmark (expressed in similar units, usually in $\mathrm{mg} / \mathrm{kg} \cdot \mathrm{d}$ for wildlife, and $\mathrm{mg} / \mathrm{kg}$ for plants and soil invertebrates). For vertebrate species, the $H Q$ represents a potential hazard to individuals of the species under consideration. An HQ greater than one indicates a potential for adverse effects. Should this be the case, site managers may elect to perform additional evaluations, such as conducting bioassays using contaminated soil from the site. The bioassays typically used at this stage assess reproduction and survivorship of earthworms in contaminated site soil, ${ }^{12,13}$ as well as plant germination and survivorshop. ${ }^{14}$ In addition, an evaluation of the actual percentage of the vertebrate species homerange that is contaminated may also be determined. Should these evaluations also indicate a potential for adverse impact, a decision is made determining the utility of conducting additional detailed studies, or conducting some form of remedial action. 


\section{Tiered Approach}

The ERA approach outlined in Fig. 1 is a step-wise approach of increasing complexity, with management decision points at each step. It has become convenient to think of each step as a tier in the ERA, with each tier involving more complex analysis. Many organizations have adopted this concept explicitly into the formulation of ERAs ${ }^{15}$. The initial tier is composed of a preliminary evaluation of pathways and receptors. The next tier is a screening analysis, in which the HQ method is often a component. Follow on tiers may include bioassays and population studies.

\section{Numerical Soil Quality Guidelines}

Risk assessors at most contaminated sites conduct screening analyses. The HQ method and other screening analysis techniques represent a significant degree of effort. Therefore, many countries are attempting to develop generic numerical soil quality guidelines (NSQGs) that are standardized ecotoxicological benchmarks. Variously called soil-screening levels, soil quality guidelines and soil protection values, they represent concentrations of contaminants in the soil below which are generically protective to ecological receptors (Table 2).

These guidelines differ with respect to land use and ecological receptor considerations. Most European NSQGs are a single value developed to protect all land uses, as the parcels of land in most of Europe are expected to be multifunctional ${ }^{16}$. The Canadian Council of Ministers of the Environment (CCME) has developed soil quality guidelines for specific land uses (agricultural, residential/parkland, commercial and industrial). Soil microbes, soil invertebrates, and plants are the ecological endpoint entities considered (herbivorous mammals are also considered in the agricultural land use scenario). Soil quality guidelines have been developed for 20 substances $^{17}$. The CCME has also released Canada-wide standards for petroleum hydrocarbon (PHC) fractions in soil ${ }^{18}$. Standards are given for four fractions (determined by normal straight-chain hydrocarbon length) in two soil types (coarse-grained and fine-grained) for the four land uses. The standards for ecological entities range from $130 \mathrm{mg} / \mathrm{kg}$ for the lightest fraction (C6 to $\mathrm{C} 10$ ) in coarsegrained surface soil in the agricultural and residential/ parkland land uses, to $10,000 \mathrm{mg} / \mathrm{kg}$ for the heaviest fraction $(\mathrm{C} 35+)$ in fine-grained subsurface soil for all land uses. The American Petroleum Institute recommends a value of 10,000 $\mathrm{mg} / \mathrm{kg}$ of total petroleum hydrocarbons in guidance on managing waste in $E \& P$ operations ${ }^{19}$.

The USEPA is in the process of developing NSQGs that they term "ecological soil-screening levels" (SSLs) for 24 contaminants (Table 3). The approach being used by the USEPA is to develop SSLs for plants, soil invertebrates, and avian and mammalian wildlife, irrespective of land use ${ }^{20}$. Three representative avian species (herbivorous dove, insectivorous woodcock, and carnivorous hawk) and three representative mammalian species (herbivorous vole, grounddwelling insectivorous shrew and carnivorous weasel) were selected. Because the SSLs are independent of land use, they should only be used on sites where appropriate exposure pathways were identified during the preliminary site evaluation. To date, only 9 contaminants have completed SSLs (Table 4). The draft SSLs, and the process used to create them, are currently in revision, following peer review.

A hurdle to developing SSLs for toxicity of petroleum hydrocarbons to vertebrates is the lack of knowledge about the bioaccumulation of hydrocarbons by biota that constitute components of the diet. The analysis of total petroleum hydrocarbons in vegetation results in estimates of natural plant hydrocarbon materials that are generally indistinguishable from those accumulated from petroleum products in soil. Thus, generic uptake factors or other models that could be used in the derivation of vertebrate SSLs are not yet available.

The basis for all of these NSQGs is essentially the HQ method, and thus the same conservative exposure assumptions apply. Toxicological benchmarks for use in NSQGs range from the $5^{\text {th }}$ percentile of the toxicity threshold and use of a safety factor on toxicological data ${ }^{16}$; the $25^{\text {th }}$ percentile of available NOAEC, LOAEC, $\mathrm{EC}_{50}$ and $\mathrm{LD}_{50}$ data ${ }^{21}$; the geometric mean of the NOAEC/ LOAEC ${ }^{20}$; and the $10^{\text {th }}$ percentile of the $\mathrm{LOAEC}^{11}$.

NSQGs are intended to be values below which it is reasonably safe to conclude that ecological receptors will not be adversely impacted. Thus, sites with soil contaminant concentrations below these values do not need to conduct additional tiers in the ecological assessment process. However, sites that exceed these numbers are expected to conduct additional evaluation. One particular problem with the use of NSQGs is that many may be lower than local background values. While most jurisdictions do not require cleanup to below background, they usually require the site to provide additional detailed information concerning site background levels. Some jurisdictions have accommodated modifying NSQGs with site-specific factors that may affect bioavailability ${ }^{16,20}$. However, it is likely many sites will be required to conduct more detailed upper-tiered ERAs.

Most jurisdictions indicate that NSQGs are not to be used as cleanup standards ${ }^{17,20}$. However, for many small sites $(<5$ ha) such as those typically found at E\&P facilities and in urban or industrial areas, it may not be cost-effective to conduct site-specific assessments or to develop site-specific remedial goals. Thus, NSQGs can become defacto cleanup levels. We do not advocate this practice.

\section{Non-chemical Screening Criteria}

To help mitigate the economic impact of conducting detailed ERAs on small sites, many states and organizations in the U.S. are developing screening criteria to supplement chemical toxicity benchmarks or SSLs to identify sites for which an ERA is not needed ${ }^{22}$. Screening criteria are designed to focus attention on sites that truly warrant a refined risk assessment effort, and to avoid even starting the ERA process for those sites where it is not appropriate. The use of screening criteria is gaining particular currency with state agencies that are responsible for contaminated sites that do not 
fall under one of EPA's major programs. The use of screening criteria in this case allows the state agency to determine if it is necessary to consider the ERA path. In a similar vein, the American Society of Testing and Materials (ASTM) currently has a task group charged with developing eco-risk-based correction action (RBCA) protocols and worksheets ${ }^{22}$.

A checklist format is sometimes used to assist the screening process at a given site (Exhibit 1) ${ }^{23}$. Screening criteria can allow for consideration of fate and transport issues, scale of release, and the potential for population-level impacts before entering the ERA process. Proximity criteria may include criteria for proximity to surface water and ground water, although numeric criteria are often not used. Ecological significance criteria may include numeric criteria for spatial extent of contamination, typically ranging from 1 to 2 acres (Washington, Texas, Louisiana, Pennsylvania and Massachusetts) ${ }^{22}$.

\section{Spatial Considerations}

One of the major challenges in both creating screening criteria and making higher-tiered ERAs more ecologically meaningful is the incorporation of spatial scale into ERAs. The earlier tiers of ERAs, as well as most NSQGs, make the assumption that all animal receptors reside $100 \%$ of the time within the contaminated area and consume only contaminated food items. Additionally, only plant and soil invertebrates within the immediate area of contamination are typically considered. Conceptually, a proportionally small extent of contamination within a habitat area results in less impact than a proportionally large extent of contamination (Fig. 3). For soil invertebrates, plants and small mammals (individuals of which may reside $100 \%$ of the time in the contaminated area), the direct mortality or other toxicological effect in the immediate area of contamination may not have population level impacts at the landscape scale. For larger, free-roaming species, the area of contamination may be a small percentage of the homerange. One way to approach this problem is to estimate the percent of habitat impacted and percent of home range used ${ }^{8,24,25}$. Another is for the assessor to randomly walk individual vertebrates through a contaminated landscape to forage ${ }^{26}$. This is typically done in higher-tiered ERAs, and probably not feasible for managers of many small-scale waste sites.

Theoretically, it should be possible to construct size criteria below which a contaminated patch of land would have negligible impact on population and ecosystem-level receptors in the area. This type of screening criteria would be particularly useful for E\&P sites, in which small spills and small area impacts typically occur within the context of a larger, intact habitat. The one-to-two acre state regulatory criteria cited above are not based on population-level analysis or landscape ecology. In practice, the use of landscape ecological analysis to identify screening criteria is complicated by the need to know the amount and quality of existing habitat across the landscape, degree of fragmentation, sensitivity of ecological receptors to habitat size and fragmentation, and cumulative impact of multiple sites ${ }^{27,28,29,30}$. Besides information on the homerange of expected or known species (Fig. 4), the overall size of the existing habitat and expected population density across the landscape needs to be considered. By using specific E\&P sites as case studies (Fig. 5), we are evaluating the impact of site-size on populations. We hope to provide information on size criteria within certain operating constraints, such as the distribution of contaminated patches within the larger landscape.

An additional tool for developing screening criteria and potentially decreasing the sampling effort required for an ecological risk assessment is the use of remotely sensed imagery. Hyperspectral data taken from aircraft, for example, may be used to delineate boundaries of oil and/or brine spills, to identify vegetation types, to identify stressed vegetation, and/or to attribute effects on vegetation to particular stressors (David Reister and Arthur Stewart, Oak Ridge National Laboratory, personal communication Dec. 2000).

\section{Bioavailability}

Bioavailability is also most typically considered in higher tiers of an ERA. Bioavailability of a contaminant may be limited due to sorption/desorption and other aging processes in the soil. Contaminants may be irreversibly sorbed onto clay or into organic matter ${ }^{31,32}$. As contaminants weather, many become less available (Fig. 6) ) $^{31,32,33,34,35}$. However, analytical techniques used at most sites measure total contaminant concentrations using very stringent extraction procedures and therefore the results are not representative of contaminants in the biologically-available fraction. Extraction procedures are being developed to mimic bioavailability. These include soil pore water extractions, extractions of the labile pool using salt solutions, and less stringent solvent extractions ${ }^{34,35,36,37}$. But even with the development of new extraction techniques, since most benchmarks and NSQGs are based on total contaminant concentrations, use of these new techniques will continue to be limited to higher tiers of the ERA. The true value of analytically determining the bioavailable fraction of contaminants will only be realized once a substantial body of data relating the biological fraction concentration to a toxicological effect is available.

Because most toxicological benchmarks are derived from tests of freshly contaminated soil, the risk assessor must be aware that they represent conservative estimates of toxicity. In refined risk assessments, toxicological benchmark concentrations are considered in the context of soil characteristics, such as organic matter and $\mathrm{pH}$. However, the primary methods to incorporate measures of bioavailability are 1) to conduct bioassays on site-specific soil samples, 2) to conduct biological surveys at the site, and 3) to measure tissue concentrations of chemicals in biota that may be related to toxicity.

\section{Summary}

The consideration of ecological receptors in site risk assessments in now considered as a matter of course. While comparing estimated exposures to toxicological benchmarks and conducting bioassays remain frequently used tools, new 
methods are on the horizon. These include the use of numerical soil quality guidelines, checklists and screening criteria, and the incorporation of the concept of bioavailability into ERAs. The need to make ERAs more applicable to ecological populations and communities is a high priority, and includes consideration of spatial distribution of ecological receptors and spill sites across the landscape.

\section{Acknowledgments}

The authors would like to thank Pat O'Brien and Sara McMillen of Chevron, and other members of the PERF 99-01 team for stimulating discussions on the concepts presented in this paper. The authors would also like to thank Nancy Comstock of the Department of Energy's National Petroleum Technology Office for financial support through the Natural Gas and Oil Technology Partnership Program. Jim Kercher and Charles Hall of Lawrence Livermore National Laboratory (LLNL) provided figures 4 and 5, respectively. Kim Heyward of LLNL provided support in preparing the figures. Work partially performed under the auspices of the U. S. Department of Energy by Lawrence Livermore National Laboratory under Contract W-7405-Eng-48 and by Oak Ridge National Laboratory under contract DE-AC05-000R22725 with UTBattelle, LLC. LLNL document number UCRL-JC-140535.

\section{References}

1. Suter, G. W.: Ecological Risk Assessment. Lewis Publishers, Boca Raton (1993).

2. U.S. EPA.: Risk Assessment Guidance for Superfund Volume II Environmental Evaluation Manual. U.S. Environmental Protection Agency. EPA 540/1-89 001. Office of Emergency and Remedial Response, Washington, D.C. (1989).

3. U.S. EPA.: Ecological Assessment of Hazardous Waste Sites: A Field and Laboratory Reference. U.S. Environmental Protection Agency. EPA 600/3-89/013. Department Office of Research and Development, Washington, D. C. (1989).

4. U.S. EPA.: Framework for Ecological Risk Assessment. U.S. Environmental Protection Agency EPA/630/R-92/001. Washington, D.C. (1992).

5. U.S. EPA.: Ecological Risk Assessment Guidance for Superfund: Process for Designing and Conducting Ecological Risk Assessments. Interim Final. U.S. Environmental Protection Agency, Environmental Response Team. Edison, NJ. (June 5, 1997).

6. U.S. EPA.: Guidelines for Ecological Risk Assessment. U.S. Environmental Protection Agency. EPA/630/R-95/002F. Risk Assessment Forum. Washington, D.C. (1998).

7. Suter, G. W. II, R. A. Efroymson, B. E. Sample, and D. S. Jones.: Ecological Risk Assessment at Contaminated Sites. Lewis Publishers. Boca Raton, Florida (2000).

8. Carlsen, T. M.: "Ecological assessment". In. C. P. WebsterScholten (ed.), Final Site-Wide Remedial Investigation Report Lawrence Livermore National Laboratory Site 300. Chapter 6, Sect. 6.2, UCAR-AR-108131. Lawrence Livermore National Laboratory, Livermore, CA. (1994).

9. Carlsen, T, M: "Ecological risks to fossorial vertebrates from volatile organic compounds in soil". Risk Analysis (1996) 16(2): 211.

10. Bench, G., T. M. Carlsen, P. G. Grant, J. S. Wollett Jr., R. E. Martinelli, J. L. Lewis, and Kevin K. Divine.: "Olfactory bulb uptake and determination of biotransfer factors in the California ground squirrel (Spermophilus beecheyi) exposed to manganese and cadmium in environmental habitats". Environ. Sci. Technol. (2001). 35: 7

11. Sample, B. E., D. M Opresko, and G. W. Suter II.: Toxicological benchmarks for wildlife: 1996 revision. Oak Ridge National Laboratory, Oak Ridge, TN. 227 pp. ES/ER/TM-86/R3 (1996).

12. Sample, B. E., Suter, G. W., II, Beauchamp, J. J., Efroymson, R. A.: "Literature-Derived Bioaccumulation Models for Earthworms: Development and Validation". Environ. Toxicol. Chem. (1999) 18: 2110.

13. Crommentuijn, T., C. J. A. M. Doodeman, A. Doornekamp, J. J. C. Van der Pol, J .J. M. Bedaux and C. A. M. Van Gestel.: "Lethal body concentrations and accumulation patterns determine time-dependent toxicity of cadmium in soil arthropods". Environ. Toxicol. Chem. (1994) 13:1781.

14. Fletcher, J. S., F. L. Johnson, and J. C. McFarlane.: "Influence of greenhouse versus field testing and taxonomic differences on plant sensitivity to chemical treatment". Environ. Toxicol. Chem. (1990) 9: 769.

15. American Petroleum Institute.: Primer for evaluating ecological risk at petroleum release sites. Prepared by Menzie-Cura \& Associates and Soza \& Company, Ltd. (February 10, 2000).

16. Nason, G. E., T. M. Carlsen, P. B. Dorn, J. Jensen, and S. B. Norton.: "Chapter 8: Soil Quality Guidelines". In Assessing Contaminated Soils: From Soil-Contaminant Interactions to Ecosystem Management. In press. Society for Environmental Chemistry and Toxicology (April 16, 1999 draft).

17. CCME.: Recommended Canadian Soil Quality Guidelines. ISBN 1-895-925-92-4. Winnipeg, Manitoba. (March 1997).

18. CCME: Canada-wide Standards for Petroleum Hydrocarbons in Soil. Winnipeg, Manitoba, (June 2000).

19. API.: Environmental Guidance Document: Waste Management in Exploration and Production Operations. American Petroleum Institute (1997) API E5.

20. U.S. EPA.: Ecological Soil Screening Level Guidance. Draft. United States Protection Agency Office of Emergency and Remedial Response, 1200 Pennsylvania Ave, N. W., Washington D.C. 20460 (July 10, 2000).

21. CCME: A Protocol for the Derivation of Environmental and Human Health Soil Quality Guidelines. CCME-EPC-101E. (1996).

22. Sorensen, M. T., J. Margolin, and B. Lawrence.: Screening Criteria Compilation. Prepared for the Gas Research Institute by ARCADIS Geraghty \& Miller, Inc. Atlanta, Georgia. GA062756/rpt1060. Draft. (10 March 2000).

23. TNRCC.: Interim Guidance for Conducting Ecological Risk Assessments at Corrective Action Sites in Texas. Texas Natural Resources Conservation Commission (TNRCC). Office of Waste Management (August 24, 1999).

24. Freshman, J. S. and C. A. Menzie.: "Two wildlife exposure models to assess impacts at the individual and population levels and the efficacy of remedial actions". Human and Ecological Risk Assessment (1996) 2:481.

25. Sample, B. E.; Rose, K. A., Suter, G.W.: "Estimation of Population Effects Based on Individual-Level Exposures: Influence of Life History Strategies". In Contaminants and Terrestrial Vertebrates: Effects on Populations, Communities, and Ecosystems. Editors: G. Heinz, H. Ohlendorf, and P. Albers. SETAC Press. USA. (1998).

26. Hope, B. K.: "Generating probabilistic spatially-explicit individual and population exposure estimates for ecological risk assessments." Risk Analysis (2000) 20:573. 
27. Villard, M. A., Trzcinski, M. K., and Merriam, G.: "Fragmentation effects on forest birds: Relative influence of woodland cover and configuration on landscape occupancy". Conservation Biology (1999) 13(4): 774.

28. Soule, M. E., Alberts, A. C., Bolger, D. T.: "The effects of habitat fragmentation on chaparral plants and vertebrates". Oikos (1992) 63(1): 39.

29. Nupp, T. E., Swihart, R. K.: "Landscape-level correlates of small-mammal assemblages in forest fragments of farmland". Journal Of Mammalogy (2000) 81(2): 512.

30. Rosenblatt, D. L., Heske, E. J., Nelson, S. L., Barber, D. H., Miller, M. A., MacAllister, B.: "Forest fragments in east-central Illinois: Islands or habitat patches for mammals?" American Midland Naturalist (1999) 141(1): 115.

31. White J. C., J. W. Kelsey, P. B. Hatzinger, M. Alexander.: "Factors affecting sequestration and bioavailability of phenanthrene in soils". Environ. Toxicol. Chem. (1997) 16:2040.

32. Lahlou, M. and J. J. Ortega-Calvo. "Bioavailability of labile and desorption-resistant phenanthrene sorbed to montmorillonite clay containing humic fractions". Environ. Toxicol. Chem. (1999) 18(12): 2729.
33. Hatzinger P. B., M. Alexander.: "Effect of aging of chemicals in soil on their biodegradability and extractability". Environ. Sci. Technol. (1995) 29:537.

34. Jin, Z., S. Simkins, and B. Xing.: "Bioavailability of freshly added and aged naphthalene in soils under gastric conditions". Environ. Toxicol. Chem. (1999) 18(12): 2751

35. Kelsey, J. W., B. D. Kottler, M. Alexander.: "Selective chemical extractants to predict bioavailability of soil-aged organic chemicals". Environ. Sci. Technol. (1997) 31:214.

36. Ruby, M. V., A. Davis, R. Schoof, S. Eberle, C. M. Sellstone:: "Estimation of lead and arsenic bioavailability using a physiologically based extraction test". Environ. Sci. Technol. (1996) 30:422.

37. Uzigirs, E. E., W. A. Edelstein, H. R. Philipp, I. E. T. Iben. "Complex thermal desorption of PCB's from soil". Chemosphere (1995) 30:377.

38. Sample, B. E., R. A. Efroymson, D. S. Jones, and G. W. Suter II.: Ecotoxicological Benchmarks for Evaluation of Exposures to Petroleum Materials. U.S. Department of Energy. National Petroleum Technology Office. ORNL/TM-13691 (September 1998).

Table 1. Example toxicological data on effects of petroleum hydrocarbons to ecological receptors (summarized from Ref. 39).

\begin{tabular}{lccc}
\hline \hline Material & Test species & Test endpoint & Toxicological result \\
\hline Kuwait crude oil & mallard & reproduction & $10,000 \mathrm{mg} / \mathrm{kg} \cdot \mathrm{d}$ NOAEL \\
North slope crude oil & ferret & $\begin{array}{c}\text { Mortality, } \\
\text { histopathology } \\
\% \text { germination }\end{array}$ & $>5000 \mathrm{mg} / \mathrm{kg} \bullet \mathrm{d} \mathrm{NOAEL}$ \\
Heavy crude & oat & $14,000 \mathrm{mg} / \mathrm{kg} \mathrm{soil} \mathrm{EC}$ \\
\hline \hline
\end{tabular}

NOAEL = no observable adverse effect concentration

$\mathrm{EC}=$ effect concentration

Table 2. Numerical Soil Quality Guidelines for selected countries. ${ }^{20}$

$\mathrm{mg} / \mathrm{kg}$ soil

protects all land uses

\begin{tabular}{|c|c|c|c|c|c|c|c|}
\hline \multirow{2}{*}{ Country } & \multirow[b]{2}{*}{ Lead } & \multirow{2}{*}{ Cadmium } & & \multirow[b]{2}{*}{ Chromium } & \multirow{2}{*}{ Mercury } \\
\hline & & & Copper & Zinc & Nickel & & \\
\hline Denmark & 40 & 0.3 & 30 & 100 & 10 & 50 & 0.1 \\
\hline Sweden $^{a}$ & $30-60$ & - & - & - & - & - & $0.2-0.3$ \\
\hline Finland & 38 & 0.3 & 32 & 90 & 40 & 80 & 0.2 \\
\hline Netherlands & 85 & 0.8 & 36 & 140 & 35 & 100 & 0.3 \\
\hline Germany $^{\mathrm{a}}$ & $40-100$ & $0.4-1.5$ & $20-60$ & $60-200$ & $15-70$ & $30-100$ & $0.1-1.0$ \\
\hline Switzerland & 50 & 0.8 & 50 & 200 & 50 & 75 & 0.8 \\
\hline $\begin{array}{l}\text { Czech } \\
\text { Republic }\end{array}$ & 70 & 0.4 & 70 & 150 & 60 & 130 & 0.4 \\
\hline $\begin{array}{l}\text { Eastern } \\
\text { Europe }\end{array}$ & 32 & 2 & 55 & 100 & 85 & 90 & 2.1 \\
\hline Ireland & 50 & 1.0 & 50 & 150 & 30 & 100 & 1.0 \\
\hline Canada & 25 & 0.5 & 30 & 50 & 20 & 20 & 0.1 \\
\hline
\end{tabular}

\footnotetext{
${ }^{a}$ lower number for sand, higher number for clay soils
} 
Table 3. Substances for which the USEPA is developing soil screening levels (summarized from Ref. 20)

Organics

Dieldrin

Total Polychlorinated Biphenyls (PCBs)

Hexahydro-1,3,5-trinitro-1,3,5-triazine (RDX)

Trinitrotoluene (TNT)

1,1,1-Trichloro-2,2-bis (p-chlorophenyl) ethane (DDT)

Pentachlorophenol (PCP)

Polycyclic Aromatic Hydrocarbons (PAHs)

Metals

$\begin{array}{lll}\text { Aluminum } & \text { Chromium } & \text { Selenium } \\ \text { Antimony } & \text { Cobalt } & \text { Silver } \\ \text { Arsenic } & \text { Copper } & \text { Vanadium } \\ \text { Barium } & \text { Iron } & \text { Zinc } \\ \text { Beryllium } & \text { Lead } & \\ \text { Cadmium } & \text { Manganese } & \end{array}$

Table 4. Soil screening levels (SSLs) that have been proposed by the USEPA (summarized from Ref. 20). $\mathrm{mg} / \mathrm{kg}$ dry weight of soil

\begin{tabular}{lcccc} 
Substance & Plants & Soil invertebrates & $\begin{array}{c}\text { Avian } \\
\text { wildlife }\end{array}$ & $\begin{array}{c}\text { Mammalian } \\
\text { wildlife }\end{array}$ \\
\hline Antimony & Pending & NA & NA & 21 \\
Arsenic & 37 & Pending & Pending & Pending \\
Cadmium & 29 & 110 & Pending & Pending \\
Chromium & 5 & Pending & 21 (III) & 360 (III) \\
Cobalt & Pending & NA & NA (VI) & 330 (VI) \\
Copper & Pending & 61 & 32 & 340 \\
Dieldrin & Pending & Pending & Pending & Pending \\
RDX & Pending & Pending & NA & 0.011 \\
Zinc & 190 & 120 & Pending & 5.8 \\
\hline
\end{tabular}

$\mathrm{NA}=$ not available. Insufficient data available to develop SSL. 


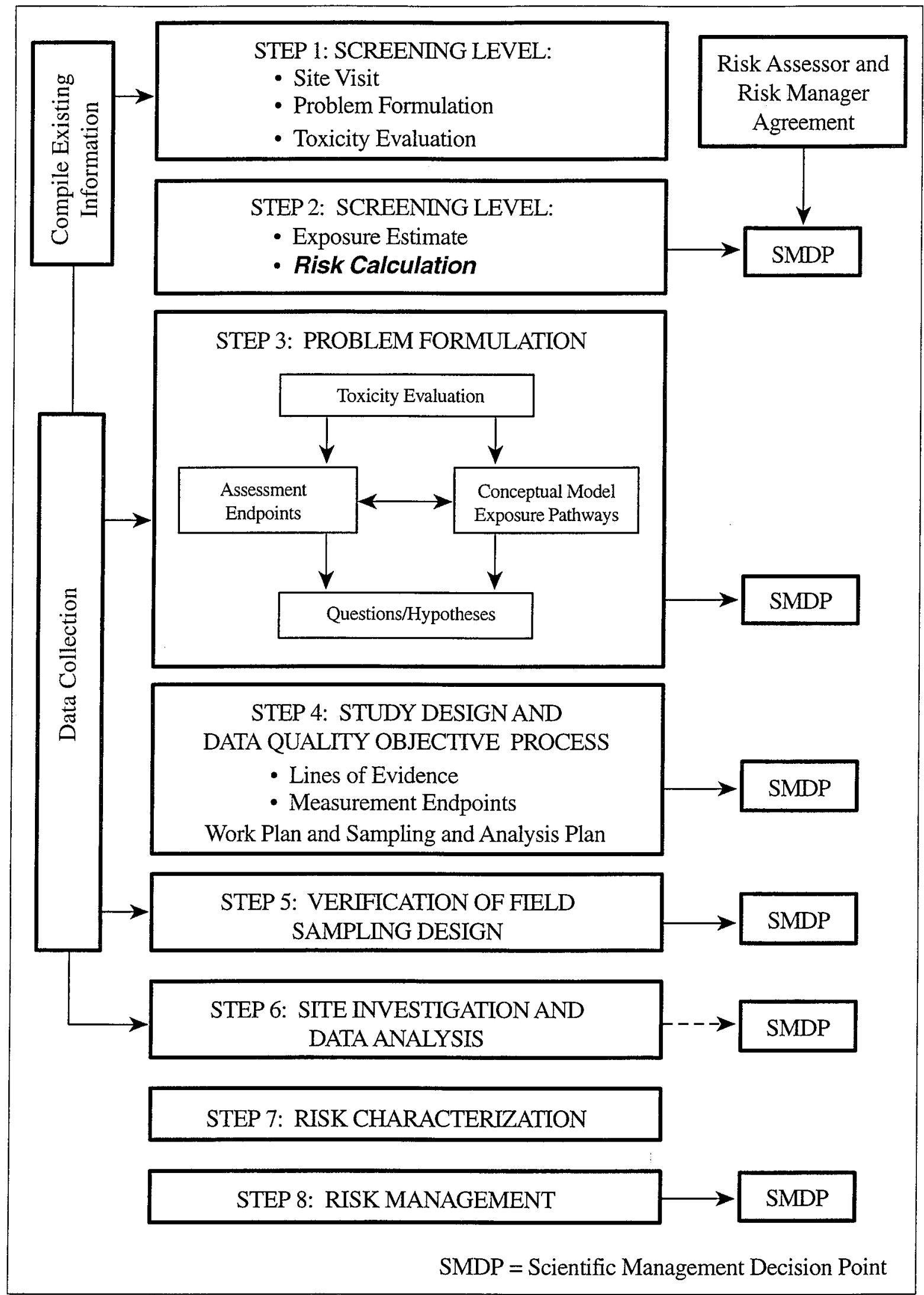

Figure 1. The eight-step process recommended by the U.S. EPA in Ecological Risk Assessment Guidance for Superfund (ERAGS) ${ }^{5}$ (figure from Ref. 20). 


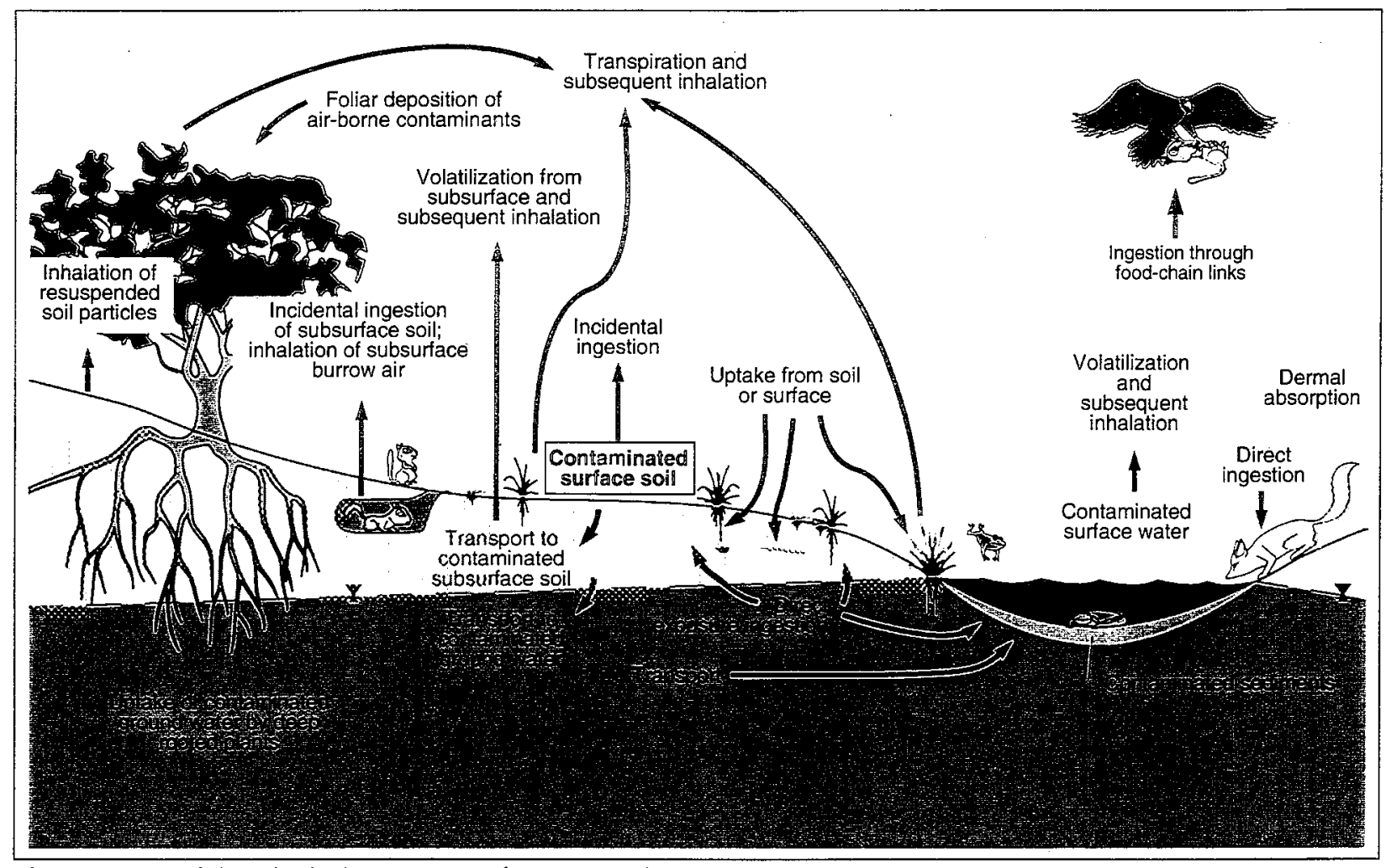

Figure 2. Potential ecological exposure pathways. 
a)

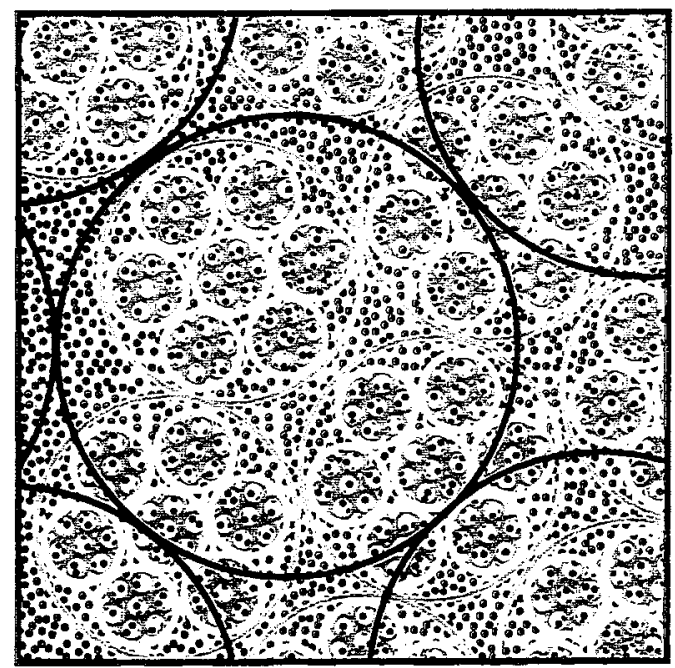

b)

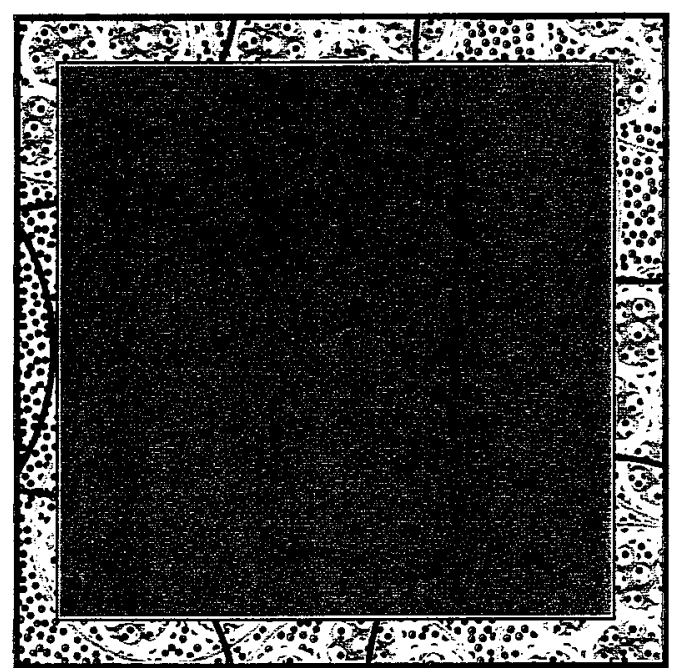

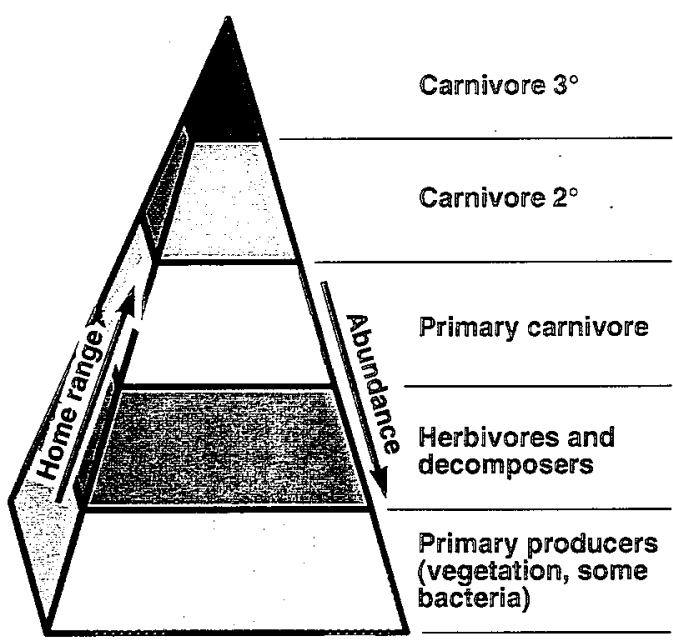

c)

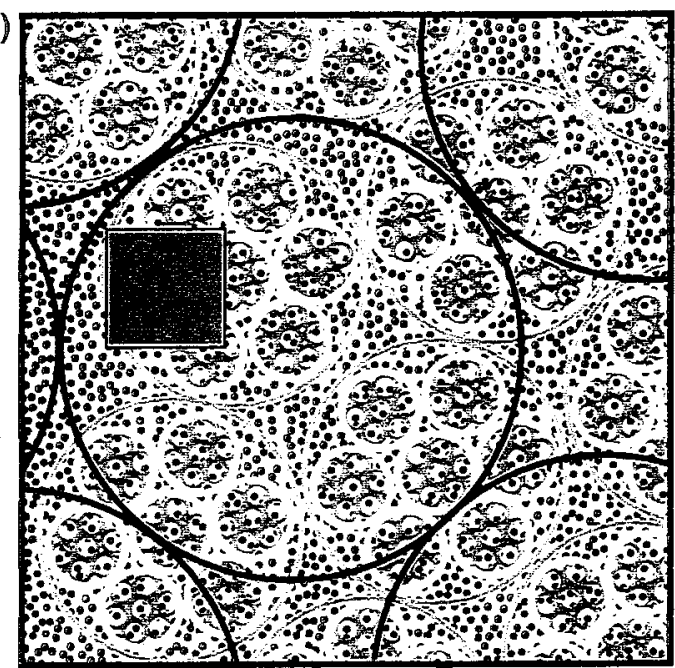

d)

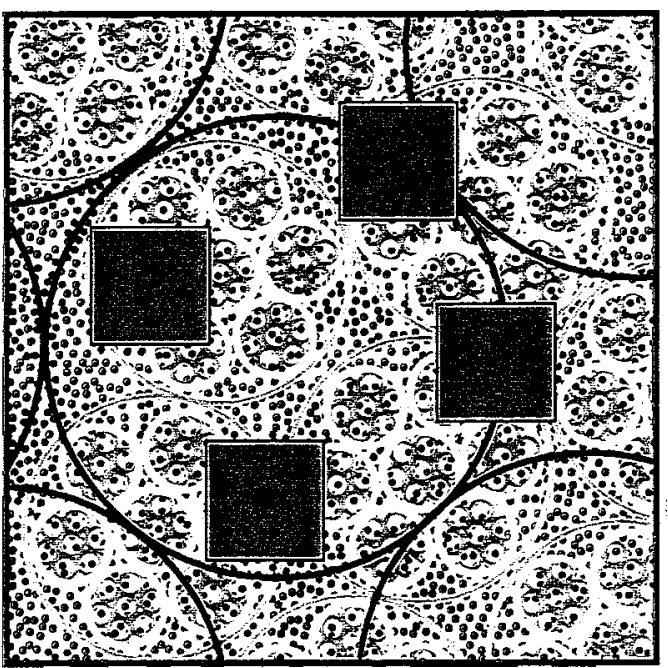

Figure 3. Relationship between site size and home range, a) relationship between trophic level and home range, b) impact of a single proportionally large site, c) impact of a single proportionally small site, and d) impact of several proportionally small sites. 


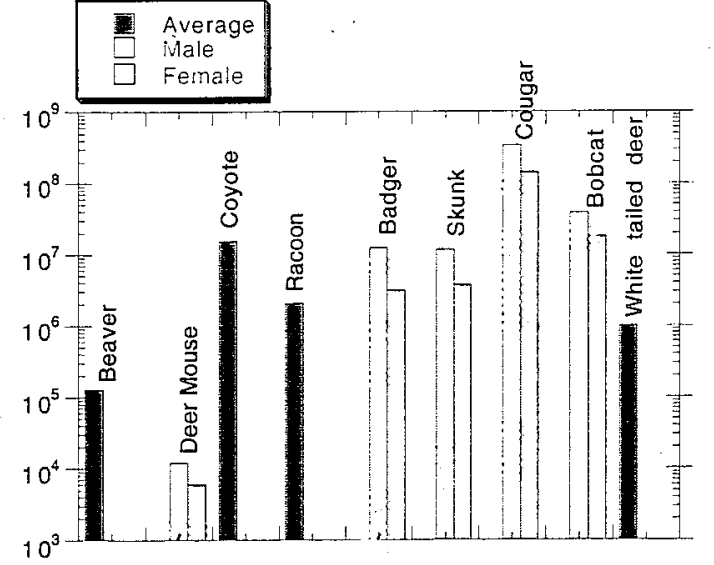

Figure 4. Home ranges depend on sex, body size, and trophic level.

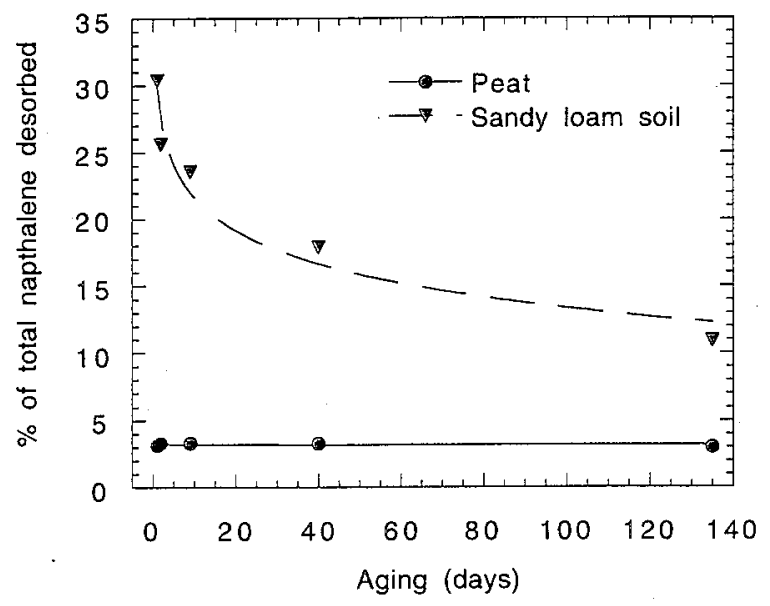

Figure 6. Percentage of total naphthalene desorbed during one month of extraction after preliminary aging in peat (39\% soil organic matter) and a sandy loam soil (2.35\% soil organic matter, $7 \%$ clay, $30 \%$ silt) after different aging periods (graph created from Ref. 34). $\mathrm{pH}$ $6.7,20 \mu \mathrm{g} / \mathrm{g}$ naphthalene applied.

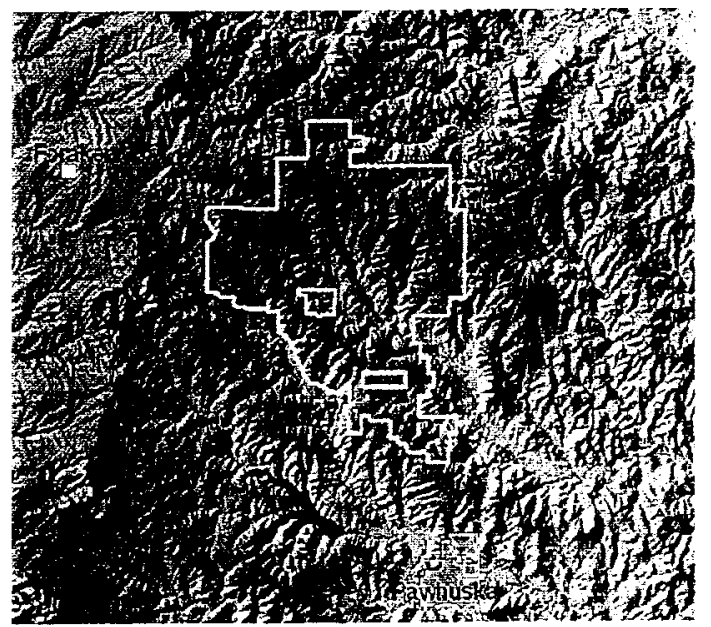

Figure 5. Tall Grass Prairie Preserve study site. Exploration and Production wells are located in the preserve, and have resulted in localized 


\section{Exhibit 1. Parts II and III of the Texas Natural Resources Conservation Commission (TNRCC) exclusion criteria checklist (taken from ref. 23)}

\section{PART II. Exclusion Criteria and Supportive Information}

\section{Subpart A. Surface Water/Sediment Exposure}

1) Regarding the affected property where a response action is being pursued under the TRRP, have COCs migrated and resulted in a release or imminent threat of release to either surface waters or to their associated sediments via surface water runoff, air deposition, groundwater seepage, etc.? Exclude wastewater treatment facilities and stormwater conveyances/impoundments authorized by permit. Also exclude conveyances, decorative ponds, and those portions of process facilities which are:

a. Not in contact with surface waters in the State or other surface waters which are ultimately in contact with surface waters in the State; and

b. Not consistently or routinely utilized as valuable habitat for natural communities including birds, mammals, reptiles, etc.

$$
\square \text { Yes } \square \text { No }
$$

Explain:

If the answer is Yes to Subpart A above, the affected property does not meet the exclusion criteria. However, complete the remainder of Part II to determine if there is a complete and/or significant soil exposure pathway, then complete PART III Qualitative Summary and Certification. If the answer is No, go to Subpart B.

\section{Subpart B. Affected Property Setting}

In answering "Yes" to the following question, it is understood that the affected property is not attractive to wildlife or livestock, including threatened or endangered species (i.e., the affected property does not serve as valuable habitat, foraging area, or refuge for ecological communities). (May require consultation with wildlife management agencies.)

1) Is the affected property wholly contained within contiguous land characterized by: pavement, buildings, landscaped area, functioning cap, roadways, equipment storage area, manufacturing or process area, other surface cover or structure, or otherwise disturbed ground?

$$
\square \text { Yes } \square \text { No }
$$

Explain:

If the answer to Subpart B above is Yes, the affected property meets the exclusion criteria, assuming the answer to Subpart A was No. Skip Subparts C and D and complete PART III - Qualitative Summary and Certification. If the answer to Subpart B above is No, go to Subpart C.

\section{Subpart C. Soil Exposure}

1) Are COCs which are in the soil of the affected property solely below the first 5 feet beneath ground surface or does the affected property have a physical barrier present to prevent exposure of receptors to COCs in surface soil?
$\square$ Yes
No

Explain: 


\section{Exhibit 1 continued}

If the answer to Subpart $\mathrm{C}$ above is Yes, the affected property meets the exclusion criteria, assuming the answer to Subpart $\mathrm{A}$ was No. Skip Subpart D and complete PART III - Qualitative Summary and Certification. If the answer to Subpart C above is No, proceed to Subpart D.

\section{Subpart D. De Minimus Land Area}

In answering "Yes" to the question below, it is understood that all of the following conditions apply:

* The affected property is not known to serve as habitat, foraging area, or refuge to threatened/endangered or otherwise protected species. (Will likely require consultation with wildlife management agencies.)

- Similar but unimpacted habitat exists within a half-mile radius.

- The affected property is not known to be located within one-quarter mile of sensitive environmental areas (e.g., rookeries, wildlife management areas, preserves). (Will likely require consultation with wildlife management agencies.)

- There is no reason to suspect that the COCs associated with the affected property will migrate such that the affected property will become larger than one acre.

1) Using human health protective concentration levels as a basis to determine the extent of the COCs, does the affected property consist of one acre or less and does it meet all of the conditions above?

$\square$ Yes $\quad \square$ No

Explain how conditions are met/not met:

If the answer to Subpart D above is Yes, then no further ecological evaluation is needed at this affected property, assuming the answer to Subpart A was No. Complete PART III - Qualitative Summary and Certification. If the answer to Subpart D above is No, proceed to Tier 2 or 3 or comparable ERA.

\section{PART III. Qualitative Summary and Certification (Complete in all cases.)}

Attach a brief statement (not to exceed 1 page) summarizing the information you have provided in this form. This summary should include sufficient information to verify that the affected property meets or does not meet the exclusion criteria. The person should make the initial decision regarding the need for further ecological evaluation (i.e., Tier 2 or 3) based upon the results of this checklist. After review, TNRCC will make a final determination on the need for further assessment. Note that the person has the continuing obligation to re-enter the ERA process if changing circumstances result in the affected property not meeting the Tier 1 exclusion criteria.

Completed by: (Typed/Printed Name) (Title)

(Date)

I believe that the information submitted is true, accurate, and complete, to the best of my knowledge.

(Typed/Printed Name of Person)

(Title of Person)

(Signature of Person)

(Date Signed) 